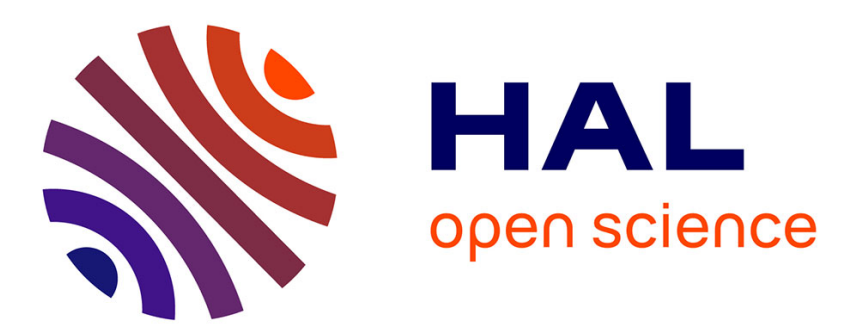

\title{
The Impact of Trade Credit on Customer Switching Behaviour: Evidence from the Tanzanian Rice Market
}

\author{
Niels Hermes, Ernest Pascal Kihanga, Robert Lensink, Clemens Lutz
}

\section{To cite this version:}

Niels Hermes, Ernest Pascal Kihanga, Robert Lensink, Clemens Lutz. The Impact of Trade Credit on Customer Switching Behaviour: Evidence from the Tanzanian Rice Market. The Journal of Development Studies, 2012, 48 (03), pp.363-376. 10.1080/00220388.2011.615921 . hal-00807099

\section{HAL Id: hal-00807099 \\ https://hal.science/hal-00807099}

Submitted on 3 Apr 2013

HAL is a multi-disciplinary open access archive for the deposit and dissemination of scientific research documents, whether they are published or not. The documents may come from teaching and research institutions in France or abroad, or from public or private research centers.
L'archive ouverte pluridisciplinaire HAL, est destinée au dépôt et à la diffusion de documents scientifiques de niveau recherche, publiés ou non, émanant des établissements d'enseignement et de recherche français ou étrangers, des laboratoires publics ou privés. 


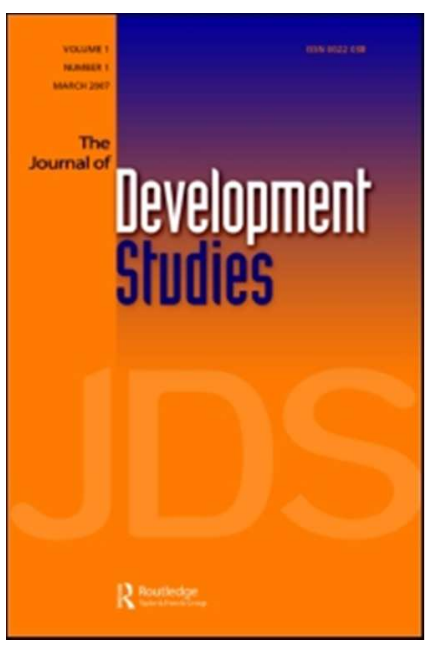

The Impact of Trade Credit on Customer Switching Behaviour: Evidence from the Tanzanian Rice Market

\begin{tabular}{|r|l|}
\hline Journal: & Journal of Development Studies \\
\hline Manuscript ID: & FJDS-2010-Oct-0005.R2 \\
\hline Manuscript Type: & Original Manuscripts \\
\hline Keywords: & $\begin{array}{l}\text { Agribusiness < Economics, Service industry < Economics, Trade < } \\
\text { Economics, Africa < Geographical Area }\end{array}$ \\
\hline \multicolumn{2}{|l}{} \\
\hline
\end{tabular}

SCHOLARONE $^{\text {m }}$

Manuscripts 


\title{
The impact of trade credit on customer switching behaviour: evidence from the Tanzanian rice market
}

\begin{abstract}
We use primary survey data to analyse the relationship between trade credit and customer switching in the context of trade transactions between wholesalers and retailers in the Tanzanian rice market. Results reveal a negative relation of trade credit and customer switching, that is, trade credit acts as a switching barrier; retailers are reluctant to move to another supplier if they depend on trade credit as a source of external finance. This interpretation fits with the underdeveloped financial markets in Tanzania, in which access to external finance is poor among rice retailers.
\end{abstract}

Key words: customer switching; trade credit; rice market; Africa; Tanzania JEL classification: L12, L14 


\section{Introduction}

Customer switching is a critical issue for suppliers of goods and services as it may adversely affect the market share and profitability of the firm (Keaveney, 1995). If customers can easily switch to new suppliers (switching costs are low) suppliers face more elastic demand, which may lead to lower mark-ups over their marginal costs, ultimately reducing the supplier's overall profitability. Recognising the potential adverse effects of customer switching, firms develop strategies to prevent it, often by increasing customer loyalty (Rust and Zahorik, 1993; Sheth and Parvatiyar, 1995; Liu, 2006). In this context, trade credit might provide a viable instrument for both preventing customer switching (McMillan and Woodruff, 1999; Cheng and Pike, 2003; Fisman and Raturi, 2004; Van Horen, 2005) and creating customer loyalty (Cheng and Pike, 2003; Bigsten and Soderbom, 2006). Yet little empirical evidence supports this claim, because studies dealing with customer switching generally overlook the role of trade credit, mostly due to a lack of sufficient data. To extend the literature, we examine explicitly whether offering trade credit can establish a switching barrier and reduce customer switching behaviour in the context of the Tanzanian rice market.

We consider this setting an interesting case for several reasons. Tanzania is a poor country with an underdeveloped financial system, so trade credit is likely to be an important source of financing for many businesses, including traders in the rice market. The results of a 2007 study reveal that approximately 70 per cent of transactions between rice wholesalers and retailers rely on credit terms. Moreover, most traders in the rice market lack access to sources of outside finance, such as bank loans (Kihanga, 2010). 
We use survey data that provide detailed cross-sectional information about 276 rice trading relationships between wholesalers and retailers in Tanzania. With this survey, we can measure different types of switching barriers that rice retailers confront, including the provision of trade credit. To the best of our knowledge, this study is the first to use detailed transaction-based data to assess the importance of trade credit as a device to curb customer switching.

In the next section, we review literature on customer switching, including a discussion of the use of trade credit to prevent such switching. We then outline the data, including our variable identification and definition. After a description of the econometric methodology and framework, we present the descriptive statistics and estimation results. Finally, we conclude and offer suggestions for further research.

\section{Customer switching: A brief review}

Customer switching refers to the migration of customers from one supplier to another, such that the customer buys goods from a different supplier (Ranganathan et al., 2006). Because customer switching adversely affects the profitability of suppliers, they tend to implement deliberate strategies, such as advertising and promotion and pursuing longterm customer relationships, to reduce the probability of customer switching. These tactics in general aim to erect switching barriers. For our analysis of customer switching behaviour in the Tanzanian rice market, we focus on deliberate strategies to create such barriers, based on long-term relationships, including the provision of trade credit ${ }^{1}$.

\section{Trade credit as a switching barrier}

Several studies have investigated the provision of trade credit by suppliers as a device to prevent customer switching (Nadiri, 1969; McMillan and Woodruff, 1999; Fisman and 
Raturi, 2004; Van Horen, 2005), usually from the perspective of resource dependency theory, which states that firms rarely are completely self-sufficient with respect to critical resources. They depend on other firms to provide these resources (Pfeffer and Nowak, 1976; Pfeffer and Salancik, 1978; Pfeffer, 1982; Heide, 1994; Paulraj and Chen, 2007).

For example, many firms are not self-sufficient when it comes to the critical resource of finance, such that they are financially constrained. Internal financial sources often are not sufficient for making short-term payments or long-term investments, nor can firms always attract external finance, such as from banks or capital markets. An alternative source of external finance therefore comes from the trade credit offered by suppliers. Trade credit may relax financial constraints of customers and cover at least their shortterm financing needs (Petersen and Rajan 1994; Nielsen, 2002).

Suppliers may not provide trade credit to all clients though. Some studies even argue that trade credit goes only to those customers with which suppliers have developed longterm relationships through repeat purchases (Biggs and Shah, 2006; Giannetti et al., 2008). Suppliers appear to prefer to establish a thorough understanding of the borrower's creditworthiness and trustfulness, to reduce their potential risk of default.

If customers depend on trade credit as a source of short-term finance, but trade credit gets supplied after the establishment of a long-term relationship, finance-dependent customers that receive trade credit are likely to persist in their existing trade relationships with suppliers, to ensure ongoing access to short-term finance (Neale and Schmidt, 1991). This dependence on trade credit thus works as a switching barrier, because switching to a new supplier may be costly: The customer could lose access to short-term finance and would have to expend time to establish a new relationship with a new supplier to gain 
access to its trade credit. In other words, the potential lack of trade credit that results from switching to a new supplier acts as a tax on customers that ties them to their current supplier.

\section{Interpersonal relationships}

Switching behaviour can also be limited by interpersonal relationships between suppliers and customers, reflecting the strength of personal ties or social bonds (Berry and Parasuraman, 1991) developed through regular contacts (Wilson, 1995). They can be described along several dimensions, such as familiarity, care, friendship, and trust (Gremler, 1995). Stronger ties imply a stronger interpersonal relationship.

The interpersonal relationships that develop between a supplier and customers can create a psychological effect on the customer's decision to switch and become a customer of a new supplier (Klemperer, 1995). Burnham et al. (2003) call this effect relational switching costs, which involve psychological or emotional discomfort associated with ending the close relationship with the supplier. This perceived discomfort creates a barrier to switching (Patterson et al., 2001). Money (2004) further shows that the perceived social consequences of switching can have negative impacts on the likelihood of switching. Finally, the strength of the interpersonal relationship often depends on the length of that relationship. Customers may prefer to continue a relationship with suppliers with which they have long trading relationships, because they have extensive experience with this supplier (Riordan and Griffet, 1995; Wathne et al., 2001; Money, 2004). This experience also can develop into a switching barrier. Empirical evidence shows that the length of a relationship between trading parties indeed reduces switching behaviour (Chakravarty et al., 2004; Money, 2004; Ranganathan et al., 2006). In the banking 
literature the length of the relationship between a bank and its clients is often used as an indicator of relational ties. Several studies have shown that these ties reduce the probability of switching (Petersen and Rajan, 1994; Berger and Udell, 1995; Chakravarty et al., 2004).

\section{Availability and attractiveness of alternatives}

The number of alternative suppliers in a market and the attractiveness of the goods and services they offer also may influence the decision to remain with or change suppliers (Colgate and Lang, 2001). When alternatives are available, the customer has a wider choice spectrum and greater possibilities for switching. In contrast, if there are no or few alternatives available, switching may be difficult, because the customer lacks viable options (Jones et al., 2000; Kiser, 2002; Roos et al., 2004). Thus, a lack of alternatives serves as a switching barrier.

A customer will consider switching to an alternative supplier if this supplier offers a product of higher quality (Kiser 2002; Patterson and Smith, 2003) or lower price (Wathne et al., 2001; Polo and Sese, 2009), as well as if the customer has a bad experience with the current supplier, provided that alternative suppliers offer better quality (Jones and Sasser, 1995). However, switching is unlikely if the available alternatives are not superior to the current supplier (Anderson and Narus, 1990; Ping, 1993; Kranton, 1996; Patterson and Smith, 2003; Tahtinen and Vaaland, 2006).

Several empirical studies confirm that alternatives in the market increase the probability of switching. Tahtinen and Vaaland (2006) show that the probability of switching declines when customers perceive a lack of alternatives, and Chen and Hitt (2002) offer evidence showing that customers with few suppliers are less likely to switch. 
Kiser (2002) finds that firms that maintain relationships with many banks (that is suppliers) often switch service providers.

\section{Search costs}

Several studies focus on the time customers need to devote to finding a new supplier that can provide the same or better goods and services than the current supplier- that is, they focus on the search costs customers must pay to switch suppliers (Dwyer et al., 1987; Klemperer, 1995; Padilla, 1995; Jones et al., 2000; Tahtinen and Vaaland, 2006). A customer needs to invest sufficient time in the relationship to obtain certain privileges (price discounts, trade credit), because many suppliers provide such privileges only to loyal customers (Biggs and Shah, 2006; Giannetti et al., 2008). The time needed to establish a trade relationship thus may reduce the probability of customer switching.

\section{Data}

The data for this study were collected through structured questionnaires distributed to rice traders in Tanzania. The questionnaire contains detailed items about specific rice trade transactions, as well as the characteristics of the parties involved in these transactions. We have information about matching pairs of participants in trade relationships; for each wholesaler included there is information about the most recent transactions with two customers (retailers) and their individual characteristics.

The sampling strategy entailed the following approach: We visited rice trade markets in different cities and randomly chose retailers to interview. The retailers provided personal information and details related to the last rice transaction in which they had been involved. After the interview, we asked the retailer to provide the name and contact 
address of the wholesaler from which he or she bought rice supplies most recently, as well as the name and contact address of another retailer that bought from the same wholesaler. We contacted the identified wholesaler and retailer and visited them to obtain information, using the same survey instrument ${ }^{2}$. With this snowball sampling approach (Goodman, 1961; Heckathorn, 1997) ${ }^{3}$, we finally managed to interview 141 wholesalers and 276 retailers. For 135 wholesalers we have detailed information about transactions with two customers; for the other six we have information about transactions with only one customer.

Before the final survey, we carried out a pilot study (May-August 2007) amongst a small sample of wholesalers and retailers. In this study we used a draft version of a structured questionnaire, which contained questions related to several characteristics of rice trade transactions, switching behaviour and the existence of switching barriers. In particular the questions pertained to the number of suppliers with which the retailer traded rice, whether the retailer had stopped buying from any specific supplier in the past two years, whether the retailer started purchasing from (that is, switched to) another supplier(s), whether the retailer was considering switching suppliers in the near future, the length of the trading relationship between the retailer and a specific supplier, the retailer's knowledge about other suppliers, whether the retailer can obtain trade credit from a new supplier in an initial transaction and whether the retailer anticipated feeling discomfort if he or she were to switch suppliers.

The final questionnaire, conducted during January-August 2008, included rice traders from the following cities: Dar es Salaam, Dodoma, Morogoro, Iringa and Mbeya. Dar es Salaam is the largest urban market centre for agricultural products. Dodoma is 
located in a region with a rice deficit. Morogoro, Iringa and Mbeya are all large regional rice surplus centres.

\section{Defining variables}

We begin with a measure of customer switching, which is our dependent variable. We measure switching with a dummy variable that is equal to 1 if a retailer stopped buying on a regular basis ${ }^{4}$ from the supplier who participated in the most recent transaction during the previous two years ${ }^{5}$. If the retailer has been buying from the same supplier over the entire two-year period, the dummy variable equals 0 . Several studies use similar measures to denote switching behaviour (Chen and Hitt, 2002; Ranganathan et al., 2006; Tseng and Liu, 2007).

Our variable of interest is trade credit received by the retailer. Trade credit is usually measured in terms of the amount of delayed payments. Based upon our discussion in section 2, we argue that retailers, who are more dependent on trade credit received from the supplier as a source of finance, are more likely to face difficulties to switch. We measure dependence on trade credit as the fraction of the total value of traded rice for which payment is delayed. This measure of trade credit is standard in literature. We expect that the retailer's willingness to switch decreases as the dependence on trade credit from the supplier increases. In other words we expect a negative relationship between the probability of switching and the amount of trade credit a retailer receives ${ }^{6}$.

Several control variables may explain switching behaviour, as we noted previously. First we include two variables that relate to the interpersonal relationships between the retailer and the supplier, reflecting perceived psychological discomfort associated with switching and the length of the trading relationship. Psychological discomfort is a dummy 
variable, equal to 1 if a retailer indicates he/she feels discomfort with the idea of replacing the supplier, and 0 otherwise. We expect a negative relationship between switching behaviour and this perceived discomfort. To take the length of the trading relationship into account, we measure the number of years a retailer has been a customer of the supplier, as used in previous studies (Chakravarty et al., 2004; Carrasco and DeMello, 2006). We expect a negative relationship between switching and the length of the relationship.

Second we include measures of the availability and attractiveness of alternative suppliers compared with the current supplier. The measure of the availability of alternative suppliers reflects the number of suppliers from which a retailer purchases rice. Because switching is easier if alternative suppliers are available, there should be a positive relationship between this variable and switching behaviour. The attractiveness of alternatives is measured in terms of whether other suppliers offer rice at a cheaper price than the current supplier. This dummy variable reveals whether the retailer notes a difference in prices for the same type of rice offered by other suppliers. If a retailer indicates no price differences, we consider it evidence of a lack of better alternatives, so the dummy variable takes a value of 1 (and 0 otherwise). A retailer seemingly has less incentive to switch if competitors do not offer rice at a cheaper price; thus we expect a negative relationship between switching and the dummy variable that measures the lack of better alternative suppliers

Third we consider the perceived time it takes to find a new supplier. As discussed in section 2 , the existence of information asymmetry requires a customer to build a close relationship with and communicate its creditworthiness to the supplier to earn privileges 
(including trade credit). The time needed to build such a close relationship with a new supplier represents a switching cost. We measure the perceived time to build a relationship with a dummy variable, taking the value of 1 if a retailer states that he or she will not get trade credit in an initial transaction with a new supplier and 0 otherwise. We expect a negative relationship between the probability of switching and this dummy variable ${ }^{7}$.

\section{Methodology}

The empirical question that this paper aims to answer is whether trade credit reduces the switching behaviour of customers. To investigate the effect of trade credit on customer switching, we model switching behaviour as a function of trade credit, including control variables that measure interpersonal relationships, the availability of alternatives and search costs. We use a probit regression model because the underlying dependent variable is a binary dummy variable. The choice for the probit model implies that we assume a standard normal distribution.

The relationship between trade credit and customer switching may suffer from a selection problem. A negative effect of trade credit on customer switching may reflect correlations between trade credit and unobserved variables that affect customer characteristics. Moreover, the causality may be reversed: if a customer does not switch, it may indicate trust in the relationship between the supplier and the customer, facilitating access to trade credit.

We address these concerns in two ways. First, we examine whether our main result disappears if we include unobserved variables that explain customer switching and at the 
same time are correlated with trade credit. In line with Altonji et al. (2005), Bellows and Miguel (2009) and Voors et al. (2011), we investigate the extent to which the coefficient of the trade credit variable changes when we include control variables. If adding the controls attenuates the trade credit coefficient, our results likely suffer from an omitted variable bias. More specifically, by comparing the coefficient of the trade credit variable in a model without controls with that in a model with a full set of controls, we can calculate the extent to which adding controls attenuates the magnitude of the estimated coefficient. By assuming that the possible bias due to selection on unobservables can be proxied by the bias due to selection on observables, we can estimate how large the selection on unobservables would need to be to explain away the entire effect of trade credit on switching.

Second we address possible endogeneity by applying an instrumental variable (IV) approach. To estimate the probit model with instrumental variables (IV probit) for trade credit, we use three variables: the log of the volume of purchase, the log of the number of years the retailer has been in business and the log of the size of the business activities of the retailer, measured by annual revenues. Transaction cost theory postulates that a larger purchase volume reduces the costs of storage and invoicing for the supplier (Petersen and Rajan, 1997). Chung and Liao (2006) confirm that these cost reductions encourage suppliers to provide trade credit. Hermes et al. (2010) show that in the Tanzanian rice market transaction costs have an important influence on the decision to provide trade credit, because the volume of purchase relates positively to trade credit.

Using financing theory, several authors (Petersen and Rajan, 1997; Summers and Wilson, 2002; Giannetti et al., 2008) identify a negative relationship among trade credit, 
firm age and firm size. That is, older and larger firms have easier access to alternative sources of external finance, such as bank loans, which attenuates their need for trade credit. When firms persist longer in business, they establish their reputation for survival, which also signals their ability to repay loans. Larger firms have better access to bank loans, because lending and monitoring costs experience economies of scale, such that it is more profitable for banks to make loans to larger firms. In the Tanzanian rice market, retailer characteristics - including the length of time in business and the size of business activities - correlate negatively with access to trade credit, in support of previous studies that test the financing theory of trade credit (Hermes et al., 2010). These retailer characteristics should help explain access to trade credit, because in Tanzania, the banking system is relatively underdeveloped, and its activities are seriously hampered by asymmetric information problems. Therefore only experienced large retailers have access to bank loans; others have to rely on trade credit.

A priori, we do not expect that the three IVs have direct relationships with switching behaviour (the correlations between the instruments and customer switching appear low). Although the validity of the instruments is tested, the 2SLS regressions have poor small sample properties so the IV estimates are treated as additional robustness checks of the probit estimates. Given the limitations of the tests used to deal with potential selection problem all results should be interpreted with reservation. The IV probit model provides a forecast value for trade credit used in the re-estimation of the model of switching behaviour. The IV Probit command in Stata is used so the two equations are estimated simultaneously (with automatic adjustment of standard errors). 


\section{The Tanzanian rice market: Descriptive statistics}

During the 1970 s and 1980s the Tanzanian rice market was strongly regulated by the Marketing Board for Cereals and the National Milling Corporation. The government overtly discouraged private grain traders. For example, the quantity that could be purchased at a time from farmers in other regions was restricted. Road blocks were used to enforce this rule. Yet, the disappointing economic performance of the Tanzanian economy and the interventionist government policies led the International Monetary Fund to insist on marketing reforms. During the late 1980s food crop markets were deregulated and controls on domestic trade of food were abolished. Since the 1990s Tanzanian food policy has been characterized by low levels of government intervention in agricultural markets.

As a result of the deregulation of the agricultural markets a large number of rice retailers and wholesalers became active in the regional and urban market places. ${ }^{8}$ Due to the fact that there are many rice suppliers active in the market, wholesalers aim at establishing a close relationship with retailers, traditionally known as uteja wa kudumu (in Swahili). As was made clear by most wholesalers during the interviews we had with them as part of our pilot study (May-August 2007), a large part of the transactions with their regular retailers is credit-based (referred to as a mali kauli transaction). The retailers we interviewed confirmed that building close relationships with suppliers improves access to trade credit and better credit terms. Finally, both wholesalers and retailers stated that close trading relationships enhance the sharing of information between trading partners. 
The above observations regarding the importance of trade credit and close relationships between trading partners in the Tanzanian rice market are corroborated by the data from our questionnaire. Table 1 presents descriptive statistics of the variables in our model of the probability of customer switching. The majority of retailers (73 per cent) have not switched in the past two years and nearly as many (67 per cent) receive trade credit from their suppliers. Trade credit thus emerges as an important financial source; losing access to trade credit may be a potential barrier to switching.

$<$ Insert table 1 here $>$

Establishing a relationship with a supplier to obtain trade credit can take time, in that 53 per cent of the retailers in the sample state that they would not get trade credit in the first transaction with a new supplier if they switched. Thus switching may be costly for a retailer. Only 25 per cent of the surveyed retailers would experience discomfort from switching to another supplier, suggesting that perceived discomfort does not appear to be a barrier for retailers. Moreover, retailers have developed relatively long trading relations with their wholesalers: The average length of trade relationships is more than four years, which implies that retailers do not switch easily. Most retailers perceive the attractiveness of alternatives as rather low. They tend to purchase rice regularly from between one and two suppliers, and a little more than half of the retailers indicate there are no price differences for the same type of rice offered by different suppliers in the market. Thus retailers appear to have low incentives to switch.

\section{Estimation results}

Table 2 presents the results of the probit regressions that indicate the probability that a customer will switch to another supplier. We first present a base model that includes only 
trade credit. In alternative specifications, we then add one or more control variables to the base model. Model 5 provides the results for the full model including all control variables ${ }^{9}$. In all these models, trade credit has a significant negative effect on the probability of switching. This result likely reflects the dependence of retailers on trade credit as a source of external finance, which should not be surprising considering the underdeveloped financial markets in Tanzania and minimal access to external financing among rice retailers. Dealing with a supplier who provides trade credit thus offers an incentive to continue the trading relationship with this supplier.

$<$ Insert table 2 here $>$

We also find support for other switching barriers. First the time it takes to establish a relationship with a new supplier before trade credit is extended acts as a barrier. Second we find that the lack of alternative suppliers that offer better prices discourages retailers from switching as changing suppliers would not result in any economic gain. The other variables used to measure switching barriers are not significant.

\section{Testing for potential selection problems}

To test for potential selection problems, we first examined whether the main result disappears if unobserved variables that explain customer switching and correlate with trade credit are included. As the results in Table 2 show, adding five observed control variables reduces the coefficient from -2.49 to -1.88 , that is, attenuates the coefficient by 0.62. In line with Bellows and Miguel (2009) we assume that the ratio between the coefficient with controls $\left(\operatorname{coef}_{c}\right)$ and the difference between the coefficient without and with controls $\left(\operatorname{coef}_{\mathrm{c}}-\operatorname{coef}_{\mathrm{nc}}\right)$ offers a proxy for how strong the covariance between the unobserved variables and trade credit must be, relative to the covariance between the 
observed variables and trade credit, to explain away the entire effect. In our case, the targeting on unobserved variables should be more than three times greater ${ }^{10}$ than the amount of targeting on observed variables if we were to explain away the entire effect of trade credit. Altonji et al. (2005) argue that the ratio of selection on unobservables relative to observables should be less than 1 . Because our ratio is 3 , this suggests that at least part of the observed effect of trade credit on customer switching is real.

We re-performed the empirical analysis that produced the results in Table 2 using an IV approach to address potential endogeneity problems. The results of the IV Probit regression results in Table 3 still suggest that trade credit has a significant negative effect on the probability of switching.

\section{$<$ Insert table 3 here $>$}

The reliability of these results clearly depends on the validity of the instruments. In the Appendix (Table A2) we provide the first-stage regression results, with trade credit as the dependent variable. The R-squared value of the first-stage regression is rather high, and two of the three instruments we used (volume of purchase and size of the retailer's business activities) are strongly significant. Our regression thus does not suffer from weak instruments. Moreover, we perform a Wald test of exogeneity to test the null hypothesis that trade credit is exogenous. The results (see Table 2) show that the $p$-value of the Wald test is very low; therefore, trade credit is endogenous, and we have support for the relevance of using instruments. Moreover, the Amemiya-Lee-Newy minimum chi square test (Table 3) to determine if the instruments are correlated with the residual from the second-stage regression is insignificant, suggesting that the instruments are valid. We 
do realize, however, that, even if the statistical tests seem to support the validity of our instruments, it does not necessarily mean that we have selected the right instruments.

Accepting the choices regarding instruments, the results in Table 3 confirm our findings from Table 2 with respect to trade credit as an important switching barrier. Even after acknowledging that trade credit is an endogenous variable, our analysis shows that the probability of retailers switching suppliers correlates negatively with the amount of trade credit they receive. Thus for retailers in the rice market in Tanzania, access to trade credit is an important impediment to switching suppliers.

The results for the other switching barriers in our model also remain similar; that is, the time it takes to establish a relationship with a new supplier before trade credit is obtained and the lack of alternative suppliers act as other barriers.

\section{Conclusions and further research}

We have analysed the relationship between trade credit and customer switching in the context of trade transactions between wholesalers and retailers in the Tanzanian rice market. Our hypothesis states that trade credit acts as a barrier that reduces the probability of customer switching. Our study is one of the first to empirically verify this claim.

Using survey data from 276 trade relations between rice wholesalers and retailers, we find evidence in support of the view that trade credit reduces the probability of customer switching. We interpret this result to indicate that trade credit acts as a switching barrier. Retailers are reluctant to move to another supplier if they depend on trade credit as a source of external finance. They could lose access to short-term finance and would have to expend time to establish a new relationship with a new supplier to gain access to trade credit. The potential lack of trade credit that results from switching to a new supplier acts 
as a tax on customers that ties them to their current supplier. The above interpretation corroborates with the status of financial markets in Tanzania, which remain underdeveloped, such that access to external finance often is minimal for rice retailers.

The relationship between trade credit and customer switching may be subject to a potential selection problem though, which prompted us to perform two tests to address this concern. We examined if our main result disappeared if we included unobserved variables that both explain customer switching and correlate with trade credit (Altonji et al., 2005), and we re-estimated the relationship between trade credit and customer switching with a probit model with instrumental variables. Both tests support our main finding that trade credit acts as a barrier to switching. However, we acknowledge the limitations of these two tests and therefore recommend that our results be interpreted with some caution.

Notwithstanding these limitations, and accepting the validity of the outcomes, our study offers several policy implications, especially for local banks in Tanzania. The finding that retailers often receive trade credit from their suppliers implies that they are credit constrained and could be potential targets for extended lending activities. Furthermore, the receipt of trade credit can be a signal of quality, because suppliers likely provide trade credit only to those retailers that represent a low risk of default on that credit. Local Tanzanian banks could use access to trade credit as a screening device for their loan decisions as well. This role of access to trade credit, that is, as a signal of a firm's credibility that can facilitate access to bank loans, also has been confirmed by Alphonse et al. (2006). 
The results of our empirical analysis are also relevant for participants in food markets in other Sub-Saharan African countries. In many of these countries food trade is an important business opportunity; yet many traders lack access to formal financial institutions. Trade credit received from their suppliers facilitates their business activities. The price they pay is a reduced freedom to switch.

One of the remaining key questions is whether trade credit improves the functioning of food markets or whether it establishes a barrier to competitive processes. Our study does not directly assess this issue. Consequently, we are unable to conclude whether or not trade credit is an efficient instrument to provide retailers access to finance. Put differently, our research does not allow us to answer the question whether trade credit in the rice market is cheaper than alternative sources of external finance as a result of lower transaction costs (reduced information asymmetry), or whether trade credit allows wholesalers to realize profits above normal rates of return as a result of lock-in (reduced threat of switching). Existing literature provides theory for both outcomes. Further research is needed to elaborate on this important issue.

On-going research should further focus on developing a setting to test more accurately for potential selection problems. Researchers also might focus on further tests of the role of trade credit in different markets and industries, both within and outside Tanzania. Finally, creating a panel data set that reveals the use of trade credit and switching behaviour would support investigations of any changes in the relationship over time, such as due to changes in the development of financial markets. 
Table 1: Descriptive statistics for variables to explain the probability of customer switching

\begin{tabular}{lccccc}
\hline \multicolumn{1}{c}{ Variable } & Observations & Mean & Standard deviation & Minimum & Maximum \\
\hline $\begin{array}{l}\text { Switching } \\
\text { behaviour }\end{array}$ & 274 & 0.270 & 0.445 & 0 & 1 \\
$\begin{array}{l}\text { Time to find } \\
\text { new supplier }\end{array}$ & 276 & 0.533 & 0.500 & 0 & 1 \\
$\begin{array}{l}\text { Number of } \\
\text { suppliers }\end{array}$ & 275 & 1.684 & 0.915 & 1 & 6 \\
$\begin{array}{l}\text { Psychological } \\
\text { discomfort }\end{array}$ & 276 & 0.254 & 0.436 & 0 & 1 \\
$\begin{array}{l}\text { Lack of } \\
\text { alternatives }\end{array}$ & 275 & 0.527 & 0.500 & 0 & 1 \\
$\begin{array}{l}\text { Length of } \\
\text { relationship }\end{array}$ & 276 & 4.214 & 1.804 & 1 & 14 \\
\begin{tabular}{l} 
Trade credit \\
\hline
\end{tabular} & 276 & 0.665 & 0.363 & 0 & 1 \\
\hline
\end{tabular}


Table 2: Standard probit regressions: Switching behaviour by retailers in the rice market of Tanzania

\begin{tabular}{|c|c|c|c|c|c|}
\hline & (1) & (2) & (3) & (4) & (5) \\
\hline $\begin{array}{l}\text { Time to find } \\
\text { new supplier }\end{array}$ & & $\begin{array}{c}-1.184 * * * \\
(0.226)\end{array}$ & & $\begin{array}{c}-1.127 * * * \\
(0.236)\end{array}$ & $\begin{array}{c}-1.1000 * * * \\
(0.265)\end{array}$ \\
\hline $\begin{array}{l}\text { Lack of } \\
\text { alternatives }\end{array}$ & & & $\begin{array}{c}-0.770 * * * \\
(0.201)\end{array}$ & $\begin{array}{c}-0.631 * * * \\
(0.216)\end{array}$ & $\begin{array}{c}-0.583 * * * \\
(0.220)\end{array}$ \\
\hline $\begin{array}{l}\text { Length of } \\
\text { relationship }\end{array}$ & & & & & $\begin{array}{l}-0.031 \\
(0.069)\end{array}$ \\
\hline $\begin{array}{l}\text { Number of } \\
\text { suppliers }\end{array}$ & & & & & $\begin{array}{l}-0.012 \\
(0.116)\end{array}$ \\
\hline $\begin{array}{l}\text { Psychological } \\
\text { discomfort }\end{array}$ & & & & & $\begin{array}{l}-0.511 \\
(0.374)\end{array}$ \\
\hline Trade credit & $\begin{array}{c}-2.497 * * * \\
(0.274)\end{array}$ & $\begin{array}{c}-2.187 * * * \\
(0.298)\end{array}$ & $\begin{array}{c}-2.406^{* * * *} \\
(0.283)\end{array}$ & $\begin{array}{c}-2.054 * * * \\
(0.305)\end{array}$ & $\begin{array}{c}-1.879 * * * \\
(0.322)\end{array}$ \\
\hline Constant & $\begin{array}{c}0.859 * * * \\
(0.179)\end{array}$ & $\begin{array}{c}1.124 * * * \\
(0.197)\end{array}$ & $\begin{array}{c}1.153 * * * \\
(0.204)\end{array}$ & $\begin{array}{c}1.305 * * * \\
(0.214)\end{array}$ & $\begin{array}{c}1.399 * * * \\
(0.399)\end{array}$ \\
\hline Observations & 274 & 274 & 273 & 273 & 272 \\
\hline Log likelihood & -109.0 & -93.8 & -101.3 & -88.8 & -87.4 \\
\hline $\begin{array}{l}\text { Pseudo R- } \\
\text { squared }\end{array}$ & 0.318 & 0.413 & 0.361 & 0.440 & 0.443 \\
\hline
\end{tabular}


Table 3: IV probit regressions: Switching behaviour of retailers in the rice market of Tanzania

\begin{tabular}{l|ll}
\hline & Coefficient & Standard Error \\
\hline Time to find new supplier & -0.614 & $0.337^{* * *}$ \\
Lack of alternatives & -0.516 & $0.245^{* *}$ \\
Length of relationship & 0.023 & 0.078 \\
Number of suppliers & 0.029 & 0.135 \\
Psychological discomfort & -0.087 & 0.432 \\
Trade credit & -3.814 & $0.857^{* * *}$ \\
Constant & 1.982 & $0.509^{* * *}$ \\
& & \\
Test of exogeneity: & & \\
Chi-square & 7.91 & \\
P-value Wald test & 0.0049 & \\
& & \\
Test of over-identifying restrictions & & \\
Amemiya-Lee-Newy Minimum Chi-sq & 3.637 & \\
P-value for Amemiya-Lee-Newy & 0.162 & \\
Minimum Chi-sq & & \\
Observations & 272 & \\
\hline
\end{tabular}

Notes: Dependent variable $=$ switching behaviour. $* * * p<0.01, * * p<0.05,{ }^{*} p<0.1$. 


\section{Appendix}

\section{Table A1: Variables used to explain probability of switching and expected signs}

\begin{tabular}{|c|c|c|c|c|}
\hline Construct & Variable name & Short definition & Measure & Expected sign \\
\hline Switching & $\begin{array}{l}\text { Switching } \\
\text { behaviour }\end{array}$ & Switching behaviour & $\begin{array}{l}1 \text { if a retailer has replaced } \\
\text { the supplier during the last } \\
\text { two years and } 0 \text { otherwise }\end{array}$ & \\
\hline Trade credit & Trade credit & Trade credit demand & $\begin{array}{l}\text { Fraction of the total value of } \\
\text { the traded rice for which } \\
\text { payment is delayed }\end{array}$ & - \\
\hline \multirow[t]{2}{*}{$\begin{array}{l}\text { Interpersonal } \\
\text { relationship }\end{array}$} & $\begin{array}{l}\text { Psychological } \\
\text { discomfort }\end{array}$ & $\begin{array}{l}\text { Perceived discomfort to } \\
\text { switch and become a } \\
\text { customer of another } \\
\text { supplier }\end{array}$ & $\begin{array}{l}1 \text { if a retailer states that it is } \\
\text { uncomfortable replacing the } \\
\text { supplier and } 0 \text { otherwise. }\end{array}$ & - \\
\hline & $\begin{array}{l}\text { Length of } \\
\text { relationship }\end{array}$ & $\begin{array}{l}\text { Duration of the } \\
\text { relationship }\end{array}$ & $\begin{array}{l}\text { Number of years a retailer } \\
\text { has been a customer of the } \\
\text { supplier }\end{array}$ & - \\
\hline \multirow{2}{*}{$\begin{array}{l}\text { Availability } \\
\text { and } \\
\text { attractiveness } \\
\text { of alternative } \\
\text { suppliers }\end{array}$} & $\begin{array}{l}\text { Number of } \\
\text { suppliers }\end{array}$ & Number of suppliers & $\begin{array}{l}\text { Number of suppliers a } \\
\text { retailer buys rice from }\end{array}$ & + \\
\hline & $\begin{array}{l}\text { Lack of } \\
\text { alternatives }\end{array}$ & $\begin{array}{l}\text { Lack of better } \\
\text { alternative supplier }\end{array}$ & $\begin{array}{l}1 \text { if the retailer perceives } \\
\text { that there is no difference in } \\
\text { prices among the suppliers } \\
\text { and } 0 \text { otherwise }\end{array}$ & - \\
\hline $\begin{array}{l}\text { Switching } \\
\text { costs }\end{array}$ & $\begin{array}{l}\text { Time to find } \\
\text { new supplier }\end{array}$ & $\begin{array}{l}\text { Perceived time needed } \\
\text { to establish a } \\
\text { relationship }\end{array}$ & $\begin{array}{l}1 \text { if a retailer states that } \\
\text { he/she will not get trade } \\
\text { credit in the first transaction } \\
\text { with a new supplier }\end{array}$ & - \\
\hline
\end{tabular}




\section{Appendix Table A2: First-stage regression, testing instrumental variables}

\begin{tabular}{|c|c|}
\hline Variables & [1] \\
\hline \multirow[t]{2}{*}{ Size of the activities of the retailer } & $-0.298 * * *$ \\
\hline & $(0.033)$ \\
\hline \multirow[t]{2}{*}{ Length of time the retailer has been in business } & 0.058 \\
\hline & $(0.056)$ \\
\hline \multirow[t]{2}{*}{ Volume of rice traded in the transaction } & $0.142 * * *$ \\
\hline & $(0.035)$ \\
\hline \multirow[t]{2}{*}{ Time to find new supplier } & $0.115^{* *}$ \\
\hline & $(0.033)$ \\
\hline \multirow[t]{2}{*}{ Lack of alternatives } & 0.045 \\
\hline & $(0.034)$ \\
\hline \multirow[t]{2}{*}{ Length of relationship } & 0.018 \\
\hline & $(0.013)$ \\
\hline \multirow[t]{2}{*}{ Number of suppliers } & 0.029 \\
\hline & $(0.021)$ \\
\hline \multirow[t]{2}{*}{ Psychological discomfort } & $0.098 * *$ \\
\hline & $(0.042)$ \\
\hline \multirow[t]{2}{*}{ Constant } & $3.390 * * *$ \\
\hline & $(0.461)$ \\
\hline F-test & 26.25 \\
\hline Prob $>F$ & 0.000 \\
\hline$R$-Squared & 0.48 \\
\hline Number of observations & 272 \\
\hline
\end{tabular}

Notes: Standard errors are in parentheses. Dependent variable $=$ trade credit. 
${ }^{1}$ Advertising and promotions generally do not play any role in this market.

${ }^{2}$ The selected retailers and wholesalers were all active in the marketplace. One may argue that they do not necessarily constitute a representative sample of traders. Regrettably, most traders active in rice markets are not formally registered. Their informal status complicates any measure of representative sampling. However, the marketplaces we visited are centers of food distribution in Tanzania, which provides some confidence that a random sampling of rice traders active in these marketplaces provides a reasonable guarantee for obtaining a representative sample.

${ }^{3}$ In snowball sampling, existing respondents recruit new respondents they know to create a sufficiently large final sample. This technique is common in sociological research that studies a population that is difficult to approach, such as drug users or alcoholics. In our case, the technique enabled us to solve the problem of finding traders who buy from the same wholesaler.

${ }^{4}$ Retailers deal with an average of 1.7 suppliers on a regular basis (see Table 1). Seasonality in supply and variation in the quality of rice forces retailers to work with more than one supplier. Thus switching implies not that retailers buy from different suppliers but rather that they cease to buy on a regular basis from a specific supplier.

${ }^{5}$ The two-year period reflects the study context. Business relationships in this market tend to be quite long. The retailers indicated that on average the business relationship with their focal supplier has lasted for more than four years (Table 1). The minimum we observed was one year. In this context retailers were asked to indicate whether they stopped buying from this supplier for some period of time during the previous two years. If the business relationship was younger than one year and the retailer had been in business for more than a year, switching had taken place.

${ }^{6}$ It could be argued that trade credit obtained recently does not influence switching in the last two years but switching in the future. Ideally our data on switching would concern the future. However, data collection on switching in the future is quite difficult to organize as it needs a second interview, later in time. Alternatively, the transaction considered in the survey could be a transaction that took place in the past. The disadvantage of such a format is the risk of imprecise answers if traders incorrectly recall their past transactions. We suggest that trade credit today is a good proxy for trade credit use in the past because it is based on past experience in the business relationship. Trade credit conditions are likely to evolve gradually as trust builds slowly.

${ }^{7}$ In the Appendix, Table A1 provides an overview of the variables used to measure switching behavior (dependent variable) and switching barriers, including trade credit (independent variables). The table also reveals the expected signs for the independent variables in the empirical analysis.

${ }^{8}$ No official data on the number of traders are available due to the fact that rice traders generally are not registered

${ }^{9}$ We do not present the results for all possible combinations of control variables, because the variables that proxy for the length of the trade relationship, the number of alternative suppliers and perceived discomfort are not significant. These variables only appear in the full model, in which we include all controls.

${ }^{10}$ Hence, $\operatorname{coef}_{\mathrm{c}} /\left(\operatorname{coef}_{\mathrm{nc}}-\operatorname{coef}_{\mathrm{c}}\right)=1.88 / 0.62=3$. 


\section{References}

Alphonse, P., Ducret, J. and Séverin, E. (2006) When trade credit facilitates access to bank finance: evidence from US small business data. Unpublished working paper, Université de Nancy.

Altonji, J., Elder, T. and Taber, C. (2005) Selection on observed and unobserved variables: assessing the effectiveness of catholic schools. Journal of Political Economy, 113(1), pp. 151-184.

Anderson, I.C. and Narus, J.A. (1990) A model of distributor firm and manufacturer firm working partnerships. Journal of Marketing, 54(1), pp. 42-58.

Bellows, J. and Miguel, E. (2009) War and local collective action in Sierra Leone. Journal of Public Economics, 93(11-12) pp. 1144-1157.

Berger, A.N. and Udell, G.F. (1995) Relationship lending and lines of credit in small firm finance. Journal of Business, 68(3), pp. 351-385.

Berry, L.L. and Parasuraman, A. (1991) Marketing Service: Competing Through Quality. (New York: Free Press).

Biggs, T. and Shah, M.K. (2006) African small and medium enterprise, networks, and manufacturing performance. Working paper series 3855, World Bank, Washington DC.

Bigsten, A. and Soderbom, M. (2006) What have we learned from a decade of manufacturing enterprise survey in Africa? World Bank Research Observer, 21(2), 241-265. 
Burnham, T., Frels, J. and Mahajan, V. (2003) Customer switching costs: a typology, antecedents and consequences. Journal of the Academy of Marketing Science, 31(2), $109-126$.

Carrasco, V. and DeMello, M.P.J. (2006) Relationship lending: is it incentives or hidden information? Discussion paper, No. 519, Departamento de Economia, PUC-Rio, Rio de Janeiro.

Chakravarty, S., Feinberg, R. and Rhee, E.Y. (2004) Relationships and individuals' bank switching behavior. Journal of Economic Psychology, 25(4), pp. 507-527.

Chen, P.Y and Hitt, M.L (2002) Measuring switching and the determinants of customer retention in internet-enabled businesses: a study of the online brokerage industry. Information System Research, 13(3), pp. 255-274.

Cheng, S.N. and Pike, R. (2003) The trade credit decision: evidence of UK firms. Management and Decision Economics, 24(6-7), pp. 419-438.

Chung, K.J. and Liao, J.J. (2006) The optimal ordering policy in a DCF analysis for deteriorating items when trade credit depends on the order quantity. International Journal of Production Economics, 100(1), pp. 116-130.

Colgate M. and Lang, B. (2001) Switching barriers in consumer markets: an investigation of the financial service industry. Journal of Consumer Marketing, 18(4), pp. 332-347.

Dwyer, F.R., Schurr, P.H. and Oh, S. (1987) Developing buyer-seller relationships. Journal of Marketing, 51(2), pp. 11-27.

Fisman, R. and Raturi, M. (2004) Does competition encourage credit provision? Evidence from African trade credit relationships. Review of Economics and Statistics, 86(1), pp. $345-352$. 
Giannetti, M., Burkart, M. and Ellingsen, T. (2008) What you sell is what you lend? Explaining trade credit contracts. Review of Financial Studies, forthcoming

Goodman, L.A. (1961), Snowball sampling. Annals of Mathematical Statistics, 32(1), pp. 148-170.

Gremler, D. (1995) The effect of satisfaction, switching costs, and interpersonal bonds on service loyalty. Doctoral thesis, Arizona State University, Phoenix, Arizona, USA.

Heckathorn, D.D. (1997) Respondent-driven sampling: a new approach to the study of hidden populations. Social Problems, 44(2), pp. 174-199.

Heide, J.B. (1994) Interorganizational governance in marketing channels. Journal of Marketing, 58(1), pp. 71-85.

Hermes, N., Kihanga, E., Lensink, R. and Lutz, C. (2010) Determinants of trade credit demand and supply in the Tanzanian rice market: a structural modeling approach. SSRN working paper, No. 1674842, University of Groningen, the Netherlands, available at SSRN (http://papers.ssrn.com/sol3/papers.cfm?abstract_id=1674842).

Jones, M.A., Mothersbaugh, D.L. and Beatty, S.E. (2000) Switching barriers and repurchase intentions in services. Journal of Retailing, 76(2), pp. 259-274.

Jones, T.O. and Sasser, W.E. (1995) Why satisfied customers defect. Harvard Business Review, 73(November-December), pp. 88-99.

Keaveney, S.M. (1995) Customer switching behavior in service industries: an exploratory study. Journal of Marketing, 59(2), pp. 71-82.

Kihanga, E.P. (2010) Trade credit use in the Tanzanian rice market, PhD Dissertation, University of Groningen, Groningen, the Netherlands. 
Kiser, E.K. (2002) Predicting household switching behaviour and switching costs at depository institutions. Review of Industrial Organization, 20(4), pp. 349-365.

Klemperer, P. (1995) Competition when consumers have switching costs: an overview with application to industrial organization, macroeconomics, and international trade. Review of Economics Studies, 62(4), pp. 515-539.

Kranton, R.E. (1996) Reciprocal exchange: a self-sustaining system. American Economic Review, 86(4), pp. 830-851.

Liu, H.A. (2006) Customer value and switching costs in business service: developing exit barriers through strategic value management. Journal of Business and Industrial Marketing, 21(1), pp. 30-37.

Money, R.B. (2004) Word-of-mouth promotion and switching behavior in Japanese and American business-to-business service clients. Journal of Business Research, 57(3), pp. 297-305.

McMillan J. and Woodruff, C. (1999) Inter-firm relationships and informal credit in Vietnam. Quarterly Journal of Economics, 114(4), pp. 1285-1320.

Nadiri, M.I. (1969) The determinants of trade credit in the U.S. total manufacturing sector. Econometrica, 37(3), pp. 408-423.

Neale, C.W. and Schmidt, R.A. (1991) Exporters' credit policy: an Anglo-West German comparative policy. European Journal of Marketing, 25(5), pp. 7-19.

Nielsen, J.H. (2002) Trade credit and the bank lending channel. Journal of Money, Credit, and Banking, 34(1), pp. 226-253.

Padilla, A.J. (1995) Revisiting dynamic duopoly with consumer costs. Journal of Economic Theory, 67(2), pp. 520-530. 
Patterson, P.G, Mandhachitara, R. and Smith, T. (2001) Switching costs as a moderator of service satisfaction processes in Thailand. Journal of International Consumer Marketing, 14(1), pp. 1-21.

Patterson, P.G. and Smith, T. (2003) A cross-cultural study of switching barriers and propensity to stay with service providers. Journal of Retailing, 79(2), pp. 107-120.

Paulraj, A. and Chen, I.J. (2007) Environmental uncertainty and strategies supply management: a resource dependence perspective and performance implications. Journal of Supply Chain Management, 43(3), pp. 29-42.

Petersen, M.A. and Rajan, R.G. (1994) The benefits of lending relationships: evidence from small business data. Journal of Finance, 49(1), pp. 3-37.

Petersen, M.A. and Rajan, R.G. (1997) Trade credit: theories and evidence. Review of Financial Studies, 10(3), pp. 661-691.

Ping, R.A. (1993) The effects of satisfaction and structural constraints on retailer exiting, voice, loyalty, opportunism and neglect. Journal of Retailing, 69(3), pp. 320-352.

Pfeffer, J. (1982) Organizations and Organization Theory (Marshfield MA: Pitman).

Pfeffer, J. and Nowak, P. (1976) Joint ventures and interorganizational interdependence. Administrative Science Quarterly, 21(3), pp. 398-418.

Pfeffer, J. and Salancik, G.R. (1978) The External Control of Organizations: A Resource Dependence Perspective (New York: Harper and Row).

Polo, Y. and Sesé, F.J. (2009) How to make switching costly: the role of marketing and relationship characteristics. Journal of Service Research, 12(2), pp. 119-137 
Ranganathan, C., Seo, D.B. and Babad, Y. (2006) Switching behavior of mobile users: do users' relational investments and demographics matter? European Journal of Information Systems, 15(3), pp. 269-276.

Riordan, M.C. and Griffet, W.R. (1995) The opportunity for friendship in the workplace: an underexplored construct. Journal of Business and Psychology, 10(2) 141-154.

Roos, I. Edvardson, B. and Gustafsson, A. (2004) Customer switching patterns in competitive and non-competitive service industries. Journal of Service Research, 6(3), pp. 256-271.

Rust, R.T. and Zahorik, A.J. (1993) Consumer satisfaction, consumer retention, and market share. Journal of Retailing, 69(2), pp. 193-215.

Sheth, J.N., and Parvatiyar, A. (1995) Relationship in consumer markets: antecedents and consequences. Journal of the Academy of Marketing Science, 23(4), pp. 255-271.

Summers, B. and Wilson, N. (2002) An empirical investigation of trade credit demand. International Journal of the Economics of Business, 9(2), pp. 257-270.

Tähtinen, J. and Vaaland, T.I. (2006) Business relationships facing the end: why restore them? Journal of Business and Industrial Marketing, 21(1), pp. 14-23.

Tseng J.Y. and Liu, S.L. (2007) Switching behavior and marketing strategy in credit card business. International Journal Electronic Customer Relationship Management, 1(1), pp. 61-74.

Van Horen, N. (2005) Trade credit as a competitive tool: evidence from developing countries, SSRN working paper, No. 562410, World Bank, Washington DC and University of Amsterdam, Amsterdam, the Netherlands, available at SSRN (http://papers.ssrn.com/sol3/papers.cfm?abstract $\mathrm{id}=904659)$. 
Voors, M.J., Nillesen, E.E.M., Bulte, E.H., Lensink, R., Verwimp, P. and van Soest, D.P. (2011) Violent conflict and behavior: a field experiment in Burundi. American Economic Review, forthcoming.

Wathne, H.K., Biong H., and Heide, J.B. (2001) Choice of supplier in embedded markets: relationship and marketing program effects. Journal of Marketing, 65(2), pp. 54-66.

Wilson, D.T. (1995) An integrated model of buyer-seller relationships. Journal of the Academy of Marketing Science, 23(4), pp. 335-345. 